\title{
Jejunum and Ileum Neuroendocrine Tumor pT3 TNM Finding v8
}

National Cancer Institute

\section{Source}

National Cancer Institute. Jejunum and Ileum Neuroendocrine Tumor PT3 TNM Finding v8. NCI Thesaurus. Code C135112.

Jejunum and ileum neuroendocrine tumor invading through the muscularis propria into subserosal tissue without penetration of overlying serosa. (from AJCC 8th Ed.) 